$21(1), 2020,49-66$
Jurnal Pendidikan MIPA
e-ISSN: 2550-1313|p-ISSN: 2087-9849
http://jurnal.fkip.unila.ac.id/index.php/jpmipa/

\title{
Model-Based Learning Approach: Effects on Students' Academic Performance and Attitudes in Earth science
}

\author{
Annalyn Cayago Canlas ${ }^{1}$, Maydeen Dizon Guevarra ${ }^{2}$ \\ ${ }^{1}$ Panipuan High School, City of San Fernando, Philippines \\ ${ }^{2}$ College of Education, Pampanga State Agricultural University, Philippines
}

\begin{abstract}
This study determined the effect of the model-based learning approach on students' academic performance and attitudes in Earth science as well as the teachers perception. A total of four science teachers served as teacher-respondents and sixty-one of ninth-grade students served as student-participants in the research. To answer the objectives of the study, the science attitudes scale, standardized test, and perception survey questionnaire were administered. T-test was utilized to determine the significant difference in the students' academic performance and attitudes in learning earth science and SWOT analysis was utilized on teachers' perception. Findings revealed that the model-based learning and conventional approaches are both effective in enhancing students' academic performance in earth science which the first approach has a positive effect on the student's attitude toward science. Moreover, SWOT analysis revealed that the model-based learning approach is a learner-centered and teacher-facilitated approach that adheres to the goal and principles of $\mathrm{K}$ to 12 Basic Education Program of enhancing learners interest and motivation, maximizing learners' $21^{\text {st }}$-century skills and scientific skills leading into holistically skill-competent learners through the model building. The overall result indicates that the model-based learning approach is a promising teaching strategy that can help improve students' academic performance and develop a positive mindset in learning science.
\end{abstract}

Keywords: model-based approach, attitudes toward earth science, academic performance.

Abstrak: Penelitian ini menentukan efek dari pendekatan pembelajaran berbasis model pada prestasi akademik dan sikap siswa dalam ilmu bumi serta persepsi guru. Sebanyak empat guru sains dan enam puluh satu siswa kelas sembilan sebagai subjek penelitian ini. Untuk menjawab tujuan penelitian, skala sikap sains, uji terstandarisasi, dan kuesioner survei persepsi diberikan. Uji Tukey digunakan untuk menentukan perbedaan yang signifikan dalam kinerja akademik siswa dan sikap dalam belajar ilmu bumi dan analisis SWOT digunakan pada persepsi guru. Temuan mengungkapkan bahwa pembelajaran berbasis model dan pendekatan konvensional keduanya efektif dalam meningkatkan kinerja akademik siswa dimana pendekatan pertama memiliki efek positif pada sikap siswa terhadap sains. Selain itu, analisis SWOT mengungkapkan bahwa pendekatan pembelajaran berbasis model adalah pendekatan yang berpusat pada peserta didik dan difasilitasi guru yang menganut tujuan dan prinsip-prinsip Program Pendidikan Dasar untuk meningkatkan minat dan motivasi peserta didik, memaksimalkan keterampilan abad ke-21, dan keterampilan ilmiah yang mengarah pada pembelajar kompeten melalui pembentukan model. Hasil keseluruhan menunjukkan bahwa pendekatan pembelajaran berbasis model adalah strategi pengajaran yang menjanjikan dalam membantu meningkatkan kinerja akademik dan mengembangkan pola pikir positif siswa dalam pembelajaran sains.

Kata kunci: pendekatan berbasis model, sikap terhadap ilmu bumi, dan prestasi akademik.

Annalyn Cayago Canlas

Email: canlas.annalyn.cayago@gmail.com
DOI: http://dx.doi.org/10.23960/jpmipa/v21i1.pp49-66

Received: 30 March 2020

Accepted: 22 June 2020 


\section{- INTRODUCTION}

Teachers have a significant influence on how students will be able to realize the importance of science in their lives and gain interest to pursue science-related courses in the future (Next Generation Science Standards, 2013). The use of relevant pedagogical approaches and skills in science teaching greatly marks students' acquisition of scientific knowledge and a deeper understanding of its application in the material world. Providing extended opportunities for students' engagement in the actual experimentation and investigative works is effective in fostering a deeper conceptual understanding of what science is (Meyer, 2014).

In the Philippines, the main vision of the revised science curriculum is geared toward producing scientifically, technologically, and environmentally literate, and productive members of the society (Science Framework for Philippine Basic Education, 2011). The learning of science is directed to equip Filipino students with relevant science skills needed to cope up with the knowledge-inclined and technology-inclined society. For many years' some Filipino students were recognized for winning in the prestigious Intel International Science and Engineering Fair (ISEF) and International Robotics Competition. However, despite the pride given from winning international science-based competitions, Filipino high school students' performance in the quality of Mathematics and Science in the last 2015-2016 showed that the Philippines ranked $67^{\text {th }}$ out of 140 countries and $79^{\text {th }}$ out of 138 in the 2016-2017 data as reported by the Global Competitiveness Report of the World Economic Forum (Dela Cruz, 2017). Also, the Philippines obtained an average Scientific Literacy score of 357 points in Programme for International Student Assessment (PISA) 2018, significantly lower than the average score of OECD, 489 points making it significantly lower than all the participating ASEAN countries (PISA 2018 National Report of the Philippines).Local studies also affirmed that Filipino students have low retention of concepts, have limited reasoning and analytical skills, and poor communication skills (they are unable to express ideas or explain natural events and phenomena in their own words) and a high percentage of Grade 6 and fourth-year students in some schools fail to integrate concepts to real-life problem-solving situations nor organize an investigation to solve a problem (UPNISMED \& DOS-SEI, 2011). These are some of the major challenges of the Department of Education to find ways on how to amplify the performance of Filipino students in the field of science education. However, it is more alarming when findings revealed that students see science as more difficult compared to other subjects (Current Challenges in Basic Science Education, 2010). Since students are taught with abstract science concepts they often find the learning process unenjoyable and irrelevant making lessons hard to understand thus decline their interest in science. Due to science complexity, abstract concepts, and unusual ideas, they are not fascinated to continue further study science-related courses (Lamanauskas, 2009). In addition, Hacieminoglu (2015) further stressed that students have negative notions and attitudes toward science due to teachers' over-dependent on textbooks, varying applications in science and technology, and different learning environments. For these reasons, short-term memory prevails which causes students to fail to progress with regard to learning standards and the development of the $21^{\text {st }}$-century skills.

In the study conducted by Barmby, Kind, \& Jones (2008), findings revealed that to improve children's attitudes towards science, learning science in school is a particular area that needs to be concentrated upon since the learners' experience of science corresponds to what they have experienced in school. This implies that learners should 
enjoy the experience of what real science is in the learning process for this will greatly impact their attitudes and aspirations toward science. Teachers being in the frontlines have a significant task on how to turn the school into a haven for active exploration of science learning experiences in the students' academic lives. The emphasis on the application of science in real- lives situations, making connections of concepts to environmental concerns, and relevance of science skills in future careers will help stimulate students' science aspirations to get involved in science-related professions in the future.

According to Hestenes (2010), the main game of science is modeling the real world, and the scientific theory serves the rule of the game. This is the main goal of science instruction to teach students how to play the modeling game of science. Therefore, the development and use of models should be put into practice in the K to 12 science classes as emphasized in the A Framework for K-12 Science Education: Practices, Crosscutting Concepts, and Core Ideas (The National Research Council, 2012). Since it was proven that the use of models in the teaching-learning process brings clarity to scientific thinking and processes (Svoboda \& Passmore, 2011), and makes abstract concepts concrete thus, easy for the students to understand (Blumschein, Ludwigs, Hung, \& Jonassen, 2009). In light of this, the Model-based learning approach complies with this call since it deals with students' engagement in creating a concrete model that will represent and explain the natural world and processes in learning science (Louca \& Zacharia, 2012). It also abides the goal of Enhanced Basic Education Curriculum ( $\mathrm{K}$ to 12 ) which highlights the use of the inquiry-based approach in the course of learning (Philippines Department of Education, 2019) because of modeling is a core practice in scientific inquiry and is the central part of scientific literacy (Passmore, Stewart, \& Cartier, 2009).

Krathwohl \& Anderson (2001) identified creating as the highest cognitive learning skill based on their revised Bloom's Taxonomy; hence, model-based learning promotes higher-order thinking skills. Since in the course of modeling activity, the students' prior knowledge of principles and concepts serve as the basis for the target system or phenomena and it is up to them what and how to construct their model as the product of learnings (Zwickl \& Hu, 2015). Teachers may introduce important terms and concepts just to facilitate the modeling activity of the students and to polish up models when it is needed making this a student-centered and teacher-assisted teaching approach (Halloun, 2007). For this reason, the teacher's guidance and strategies in facilitating model-based learning depend primarily on his knowledge on the nature and functions of models (Davis, 2011) and it also depends on how students will rebuild their mental models (Moutinho \& Vasconcelos, 2017). According to Johnson-Laird Mental Modeling Theory (1983), mental models are the artifacts of the real-world systems; and make natural processes and phenomena observable that can never be felt or seen right before the eyes (Clement, 2008). Thus, active engagement on hands-on activities is essential for it helps students to learn and appreciate how scientific processes work that lead to the retention of learning.

Without a firm grasp of an expressed product or model- the end product of science built from the process of discovery and inquiry, students will be deprived of what science is (Gilbert, 2011). However, the findings of Schwarz (2009) among preservice teachers revealed they do not see modeling as an important inquiry-based approach in science; thus, they are not confident enough to employ the Model-based learning approach in teaching science. 
Although the effectiveness of the model-based learning approach has been already proven, previous studies were conducted in foreign setup and focused mostly on its effect on students' attitudes toward science and the development of students' mental models. The possible effects of the Model-based learning approach on students' performance and attitudes have not been studied in the Philippines setting particularly in teaching Earth science. For these reasons, the researcher would like to determine the effect of the model-based learning approach in students' performance and attitudes towards Earth science as well as the teachers' perception in employing this strategy in teaching. The result of this study can be used as a basis of science teachers in developing a modified activity module aligned with the model-based learning approach.

\section{- METHOD}

\section{Research Design}

This research used both quasi-experimental research using the pretest-posttest design and qualitative method of research. A quasi-experimental method was used to determine the performance and attitude of the students in the model-based learning Approach; while the qualitative method was utilized to determine the teachers' perception of the strength, weaknesses, opportunities, and threats of the treatment. The conventional approach was administered among the control group while the modelbased learning Approach was utilized among the experimental group.

\section{Research Instruments}

There were three instruments used in the study. The first one is a 25-item multiple-choice pretest from the combined pretests found on the Grade 9 Science Learner's Module and DepEd Project EASE Integrated Science I which later on rearranged and used as a posttest. The second instrument was a Science Attitudes Scale developed by Barmby, Kind, and Jones (2008). It was a 37-item Likert-type questionnaire that measures the following areas: Learning science in school, Selfconcept in science, Practical work in science, Science outside of school, Future participation in science, and the Importance of science. The questionnaire items were coded numerically $(5=$ Strongly agree, $4=$ Agree, $3=$ Uncertain, $2=$ Disagree and $1=$ Strongly disagree; these were reversed for negatively worded items). The values for any of the attitudes towards science measures for the group could vary between 1 (most negative) and 5 (most positive). Lastly, the third instrument was an interview questionnaire developed by the researcher. It was validated by the three (3) expert professors of Pampanga State Agricultural University. The questionnaire served as the basis for the qualitative analysis of the teacher-respondents' perception of the strengths, weaknesses, opportunities, and threats of the model-based learning Approach. A Table of Specification, model-based learning Approach activity sheets, and Daily Lesson Log used in the teaching process was also part of the research instruments.

\section{Sampling Procedure}

A total of sixty-one (61) $9^{\text {th }}$-grade student-participants and four (4) Science teacher-respondents participated in the entire study. Two intact classes were randomly selected which were heterogeneously categorized during enrolment based on their final average in their $8^{\text {th }}$ grade. In determining the control and experimental group, a fishbowl technique was utilized. Grade 9 - Peace was the control group while Grade 9 - Loyalty was the experimental group. There were thirty-one (31) students composed of fifteen 
(15) males and sixteen (16) females in the control group and thirty (30) students composed of seventeen (17) males and thirteen (13) females in the experimental group. Whereas, total enumeration was utilized in determining the teacher-respondents. There were four (4) science teachers handling Science 7, Science 8, Science 10, and Science 11 to 12 who served as the teacher-respondents in this study. The study was conducted during the $3^{\text {rd }}$ Quarter of the Academic Year 2017-2018. To assure the validity of the study, two parameters were observed. First, both classes were heterogeneous and exposed to the same experience regarding room conditions, ventilation, and school schedules.

The pretest and Science Attitudes Scale was employed to both groups to determine their prior knowledge of the lessons and prior attitudes toward Science before the treatment. As the study began, each group was exposed in their respective learning strategy while learning about the concepts on the Characteristics of stars, Arrangement of Stars in a Group, Changing Position of Constellations during the Night and at Different Times of the Year and Beliefs and Practices about Constellations and Astrology found on Module 9 of Science 9 Learners' Material. The topics were discussed among both classes which were divided into small groups for the activity and exposed to the same experience except the differential treatment as described.

The conventional class experienced the conventional way of learning science aided with video clips and PowerPoint presentations and executed the activities found on the Science 9 Learner's Module. However, in the Model-Based class, they applied the five steps of the model-based learning Approach (Fretz et al., (2002): (1) observation and data collection - concepts were introduced by the teacher through PowerPoint presentations and video clips which served as the basis for the target model; (2) construction of a preliminary model -students executed the modified version of activities aligned with model-based learning Approach made by the teacher where they constructed a concrete model using localized materials guided by a rubric. Except for the purpose of the model, it was the students' choice of what and how would they build the model. The constructed model was used to answer the guide questions of the activity; (3) application - the constructed model was justified and explained in class to answer the guide questions; (4) evaluation -assessment of model in line with the rubric; and, (5) revision of the preliminary model - revision of the output model as to the teacher's evaluation and suggestions. The learning process and modeling activity were recorded for the teacher-respondents' evaluation.

After being exposed to the respective teaching strategy, a posttest was administered to the control group and experimental group to determine the effect of the two methods on the achievement of the students. Also, the Science Attitudes Scale questionnaire was utilized again to the student-participants to determine their attitudes toward science after being exposed to the two teaching approaches.

\section{Data Analysis}

In analyzing the data, the Statistical Package for Social Sciences (SPSS) was utilized. Mean and the standard deviation was used to quantify the scores of the participants in their pretest and posttest. To determine if there was a significant difference between the scores of the two groups before and after using the conventional and model-based learning approach, a paired sample t-test and independent-sample ttest were employed. Also, the students' responses in the Science Attitudes Scale were 
coded numerically to determine their mean scores and interpreted using descriptive statistical measures.

To identify the perception of the teacher-respondents on the model-based learning approach, an interview questionnaire was employed upon viewing the videos captured during the modeling activities of the students. The teacher-respondents' responses were consolidated and examined using the SWOT Analysis to determine the strength, weaknesses, opportunities, and threats of the model-based approach in teaching and learning selected topics in earth science.

\section{- RESULT AND DISCUSSION}

Table 1 shows the performance of the students before and after the experiment in both groups. The lowest score in the conventional method was 5 and its highest score was 15 with a mean score of 10.387 and a standard deviation of 2.565 in their pretest result. Whereas the pretest result of the model-based group obtained the lowest score of 4 but it obtained the highest score of 18 with a mean score of 11.900 and a standard deviation of 3.661. Overall, the results revealed that both groups were statistically equivalent to prior knowledge before the treatment. Both groups had little preliminary knowledge about the lesson as shown in their failing scores in the pretest.

Table 1. Performance of the participants in the pretest and posttest in earth science using the conventional and model-based learning

\begin{tabular}{lllllllll}
\hline \multirow{2}{*}{ Method } & \multicolumn{4}{c}{ Pretest } & \multicolumn{5}{c}{ Posttest } \\
\cline { 2 - 10 } & Mean & SD & HS & LS & Mean & SD & HS & LS \\
\hline Conventional approach & 10.387 & 2.565 & 15 & 5 & 16.774 & 4.551 & 24 & 8 \\
\hline Model-based learning & 11.900 & 3.661 & 18 & 4 & 18.533 & 4.392 & 25 & 10 \\
\hline
\end{tabular}

After being exposed to their respective teaching strategy, the posttest results of the conventional group obtained the lowest score of 8 whereas the highest score was 24 with a mean score of 16.774 and a standard deviation of 4.551. On the other hand, the posttest result of the model-based group reveals that the lowest score was 10 and got the highest score of 25 with a mean score of 18.533 and a standard deviation of 4.392 . Generally, the results conveyed that both groups had acquired the needed knowledge and improved their performance in earth science as shown in the results of their posttest scores, revealing that the participants obtained passing scores after being exposed to the two teaching approaches.

This result supports to what Moutinho, Moura, \& Vasconcelos (2017) stated that model-based learning helps students to have a deeper understanding of how natural processes or phenomena work through the use of models while the findings of Liu \& Long (2014) revealed that in the traditional method of teaching as it is being a teachercentered method inspires and motivates students to perform well in class due to constant face-to-face interaction existing among them. This supports the findings of Balliu \& Belshi (2017) that students are more focused on the lesson and perform well in class when the traditional way of teaching is employed in teaching science. 
Table 2. Attitudes of the participants in the conventional approach and model-based approach before the experiment

\begin{tabular}{lllll}
\hline \multirow{2}{*}{ Attitude Statements } & \multicolumn{2}{c}{ Conventional approach } & \multicolumn{2}{c}{ Model-based learning } \\
\cline { 2 - 5 } & Mean & $\begin{array}{l}\text { Descriptive } \\
\text { rating }\end{array}$ & Mean & $\begin{array}{l}\text { Descriptive } \\
\text { rating }\end{array}$ \\
\hline Learning science in school & 3.87 & Positive & 4.07 & Positive \\
\hline Self-concept in science & 3.29 & Neutral & 3.41 & Neutral \\
\hline Practical work in science & 3.87 & Positive & 3.83 & Positive \\
\hline Science outside the school & 3.76 & Positive & 3.87 & Positive \\
\hline Future participation in science & 3.09 & Neutral & 3.19 & Neutral \\
\hline Importance of science & 4.08 & Positive & 3.99 & Positive \\
\hline Grand mean & $\mathbf{3 . 6 6}$ & Positive & $\mathbf{3 . 7 3}$ & Positive \\
\hline
\end{tabular}

Table 2 presents the mean scores of both groups reflecting their attitudes in Science before the experiment. For the interpretation of data, the mean scores were illustrated using descriptive ratings which were as follows: $4.5-5.00=$ Very Positive, $3.5-4.49=$ Positive, $2.5-3.49=$ Neutral, $1.5-2.49=$ Negative, and $1.0-1.49=$ Very Negative. The data revealed that both the conventional and model-based groups obtained a descriptive rating of positive towards Learning Science in School, Practical work in Science, Science outside the school and Importance of science with mean scores of $3.87,3.87,3.76$ and 4.08, respectively for the conventional group while 4.07, $3.83,3.87$, and 3.99 for the model-based group. This implied that the two groups had positive attitudes towards these areas of science before the experiment. However, in terms of Self-concept in Science and Future Participation in Science, the two groups obtained a descriptive rating of neutral with mean scores of 3.29 and 3.09, respectively for the conventional group and 3.41 and 3.19 mean scores for the model-based group. These results revealed that the two groups were not sure of their Science abilities and were not confident either to take science-related courses in the future or take careers anchored to science.

Several studies claimed (Ali \& Awan, 2013; DeWitt et al., 2011; Soomro, Qaisrani, \& Uqaili, 2011) that the attitude to school science is an influential factor that impacts students' aspirations towards professional studies inclined to science in the future. If students manifest positive attitudes in science they are more inspired to get involved in science-related careers in the future.

Table 3.Attitudes of the participants in the conventional approach and model-based approach after the experiment

\begin{tabular}{lllll}
\hline \multirow{2}{*}{ Attitude statements } & \multicolumn{2}{c}{ Conventional approach } & \multicolumn{2}{c}{ Model-based learning } \\
\cline { 2 - 5 } & Mean & $\begin{array}{l}\text { Descriptive } \\
\text { rating }\end{array}$ & Mean & $\begin{array}{l}\text { Descriptive } \\
\text { rating }\end{array}$ \\
\hline Learning science in school & 3.81 & Positive & 4.09 & Positive \\
\hline Self-concept in science & 3.26 & Neutral & 3.54 & Positive \\
\hline Practical work in science & 3.78 & Positive & 4.03 & Positive \\
\hline Science outside the school & 3.66 & Positive & 3.78 & Positive \\
\hline $\begin{array}{l}\text { Future participation } \\
\text { in science }\end{array}$ & 3.10 & Neutral & 3.18 & Neutral \\
\hline
\end{tabular}




\begin{tabular}{lllll}
\hline Importance of science & 3.99 & Positive & 4.17 & Positive \\
\hline Grand Mean & $\mathbf{3 . 6 0}$ & Positive & $\mathbf{3 . 8 0}$ & Positive \\
\hline
\end{tabular}

Table 3 reveals the mean scores of both groups reflecting their attitudes in Science after the experiment. For the interpretation of data, the mean scores were illustrated using descriptive ratings which were as follows: $4.5-5.00=$ Very Positive, $3.5-4.49=$ Positive, $2.5-3.49=$ Neutral, $1.5-2.49=$ Negative, and $1.0-1.49=$ Very Negative. The data revealed that the conventional and model-based groups obtained a descriptive rating of positive which means that both groups had positive attitudes towards Learning Science in School, Practical work in Science, Science outside the school and Importance of science with mean scores of 3.81, 3.78, 3.66 and 3.99, respectively for the conventional group while 4.09, 4.03, 3.78, and 4.17 for the modelbased group. The manifestation of positive attitudes in science improves students' academic performance according to the findings in the study conducted by Lacap (2015). On the other hand, in terms of Future participation in Science, the two groups obtained a descriptive rating of neutral with a mean score of 3.10 for the conventional group while 3.18 mean score for the model-based group. This result indicated that the two groups were not still sure to take courses or have a job related to science in the future.

As stated in the findings of Akcay, Yager, Iskander, \& Turgut, (2010), the attitudes of students toward science greatly influenced how they will perceive science, gain interest to pursue science courses, and participate in the learning process. On the other hand, in terms of Self-concept in Science, the conventional group obtained a mean score of 3.26 with a descriptive rating of neutral. This means that the group either had positive or negative attitudes toward this area in science which means they were not sure of how good they were in science. Whereas, the model-based group had a mean score of 3.54 with a descriptive rating of positive which means that students under this group had increased their confidence and improved their attitude positively in terms of academic abilities to perform well in science. According to the findings of the study conducted by Guay et al. (2010), academic self-concept influences students' performance. Students who have a positive attitude toward their academic ability tend to get higher grades due to an optimistic view point and self-confidence to perform well in class.

Table 4. Attitudes of the participants in the conventional approach and model-based approach before and after the experiment towards learning science in school

\begin{tabular}{llllll}
\hline \multirow{2}{*}{$\begin{array}{l}\text { Attitude } \\
\text { statement }\end{array}$} & \multirow{2}{*}{ Method } & \multicolumn{2}{l}{ Mean score } & \multirow{2}{*}{ p-value } & \multirow{2}{*}{ Interpretation } \\
\cline { 2 - 6 } & Before & After & & \\
\hline \multirow{3}{*}{$\begin{array}{l}\text { Learning } \\
\text { science in } \\
\text { school }\end{array}$} & 3.87 & 3.81 & 0.531 & not significant \\
\cline { 2 - 6 } & MBL & 4.07 & 4.09 & 0.805 & not significant \\
\cline { 2 - 6 } & p-value & 0.11 & 0.056 & & \\
\cline { 2 - 5 } & Interpretation & $\begin{array}{l}\text { not } \\
\text { significant }\end{array}$ & $\begin{array}{l}\text { not } \\
\text { significant }\end{array}$ & & \\
\hline
\end{tabular}

Table 4 shows the attitudes of the participants towards learning science in school before and after the experiment. As depicted from the table, the conventional approach group (CA) had a mean score of 3.87 before the experiment and a 3.81 mean score after 
the experiment with a p-value of 0.531 ; while the model-based group (MBL) had a mean score of 4.07 before the experiment and 4.09 after the experiment with a p-value of 0.805 . The results indicated that there was no significant difference between the attitude of the students before and after the experiment in terms of their interest in learning science. This revealed that students had the same attitude toward Learning Science before and after being exposed to the two teaching approaches. Students in both groups had a positive attitude on the way they learn science in school.

On the other hand, in comparing the two groups, the conventional group obtained a p-value of 0.110 while the model-based group got a p-value of 0.056 . The results indicated that there was no significant difference between the two groups which means that the students from both groups had the same attitude in terms of how they see Learning Science in School before and after the treatment. Based on the findings of the study conducted by Barmby, Kind, and Jones (2008), learning science in school should be given priority if the goal is to improve the learners' attitude toward science. The learners' experience of science is congruent with what they have experienced in school. This poses that learners should enjoy the experience of what science really in the course of learning science for this will influence their attitudes and foster aspirations to science-based careers in the future.

Table 5. Attitudes of the participants in the conventional approach and model-based approach before and after the experiment towards self-concept in science

\begin{tabular}{llllll}
\hline \multirow{2}{*}{$\begin{array}{l}\text { Attitude } \\
\text { statements }\end{array}$} & \multirow{2}{*}{ Method } & \multicolumn{2}{l}{ Mean score } & p-value & Interpretation \\
\cline { 2 - 6 } & & Before & After & & \\
\hline \multirow{3}{*}{$\begin{array}{l}\text { Self- } \\
\text { concept } \\
\text { in Science }\end{array}$} & CA & 3.29 & 3.26 & 0.796 & not significant \\
\cline { 2 - 6 } & MBL & 3.41 & 3.54 & 0.230 & not significant \\
\cline { 2 - 6 } & p-value & 0.288 & 0.046 & & \\
\cline { 2 - 6 } & Interpretation & $\begin{array}{l}\text { not } \\
\text { significant }\end{array}$ & significant & & \\
\hline
\end{tabular}

Table 5 presents the attitudes of the participants in terms of Self-concept in Science before and after the experiment. As depicted in the table, the conventional group (CA) obtained a mean score of 3.29 before the experiment and 3.26 mean score after the experiment with a p-value of 0.796 while the model-based group (MBL) gathered a mean score of 3.41 before the experiment and 3.54 mean score after the experiment with a p-value of 0.230 . The results revealed that there was no significant difference in each group before and after the treatment in terms of their attitude toward Self-concept in Science. This means that students in both groups had the same attitude toward how they feel about how good they are in science before and after being exposed in each respective treatment. Whereas in comparing the two groups, the p-value of 0.288 before the experiment and $0.046 \mathrm{p}$-values after the experiment implied that there was a significant difference between the two groups after the treatment in favor of the model-based group. This means that the model-based group had gained a positive attitude about how good they are towards science. Several studies revealed (Jaiswal \& Choudhuri, 2017; Jansen, Schroeders, \& Lüdtke, 2014; Marsh \& Martin; 2011) that the development of positive academic self-concept of students toward science is essential to boost their confidence in their ability to do well in science leading to academic achievement and optimize performance hence, it should be given much priority. In 
addition, students who have positive self-concept toward science tended to have higher aspirations in science (DeWitt et. al., 2013).

Table 6. Attitudes of the participants in the conventional approach and model-based approach before and after the experiment towards practical work in science

\begin{tabular}{|c|c|c|c|c|c|}
\hline \multirow{2}{*}{$\begin{array}{l}\text { Attitude } \\
\text { Statements }\end{array}$} & \multirow{2}{*}{ Method } & \multicolumn{2}{|c|}{ Mean Score } & \multirow{2}{*}{ p-value } & \multirow{2}{*}{ Interpretation } \\
\hline & & Before & After & & \\
\hline \multirow{4}{*}{$\begin{array}{l}\text { Practical } \\
\text { Work in } \\
\text { Science }\end{array}$} & $\mathrm{CA}$ & 3.87 & 3.78 & 0.314 & not significant \\
\hline & MBL & 3.83 & 4.04 & 0.052 & not significant \\
\hline & p-value & 0.785 & 0.081 & & \\
\hline & Interpretation & $\begin{array}{l}\text { not } \\
\text { significant }\end{array}$ & $\begin{array}{l}\text { not } \\
\text { significant }\end{array}$ & & \\
\hline
\end{tabular}

Table 6 reveals the attitudes of the participants in terms of practical work in science before and after the experiment. The conventional group (CA) obtained a mean score of 3.87 before the experiment and 3.78 after the experiment with a p-value of 0.314 while the model-based group (MBL) gained a mean score of 3.83 before the experiment and 4.04 mean score after the experiment with a p-value of 0.052 . The results indicate that there was no significant difference in terms of how the students in both groups see Practical works in science before and after the treatment. This means that students in both groups did prefer performing practical works or hands-on activities in the course of learning science before and after being exposed to each respective teaching approach. Whereas in comparing the two groups, the conventional group and model-based group had p-values of 0.785 and 0.081 , respectively, which means that there was no significant difference between the two groups. This result conveyed that students in both groups preferred to be engaged in practical activities while learning science. The result affirmed the findings of by Abrahams (2007) that secondary school students mostly like practical work or at least prefer it compared to other kinds of lesson activities since it makes science ideas observable and this supports the findings in the study of Needham (2014) that practical works foster learning, motivate students to work actively. This is parallel to the findings of Okam \& Zakari (2017) that practical works elicit positive attitudes geared toward the mastery of science concepts and the acquisition of scientific skills.

Table 7. Attitudes of the participants in the conventional approach and model-based approach before and after the experiment towards science outside the school

\begin{tabular}{llllll}
\hline \multirow{2}{*}{ Attitude } & \multirow{2}{*}{ Method } & \multicolumn{2}{l}{ Mean score } & \multirow{2}{*}{ p-value } & Interpretation \\
\cline { 3 - 6 } & & Before & After & & \\
\hline \multirow{3}{*}{$\begin{array}{l}\text { Science } \\
\text { outside the } \\
\text { school }\end{array}$} & CA & 3.76 & 3.66 & 0.358 & not significant \\
\cline { 2 - 6 } & MBL & 3.87 & 3.78 & 0.213 & not significant \\
\cline { 2 - 6 } & p-value & 0.475 & 0.434 & & \\
\cline { 2 - 5 } & Interpretation & $\begin{array}{l}\text { not } \\
\text { significant }\end{array}$ & $\begin{array}{l}\text { not } \\
\text { significant }\end{array}$ & & \\
\hline
\end{tabular}

Table 7 shows the attitudes of the participants in terms of science outside the school before and after the experiment. The conventional group (CA) obtained a mean score of 3.76 before the experiment and 3.66 after the experiment with a p-value of 
0.358 while the model-based group (MBL) gained a mean score of 3.87 before the experiment and 3.78 mean score after the experiment with a p-value of 0.213 . The results indicated that there was no significant difference in each group concerning Science outside the school before and after the treatment. This means that each group had the same attitude in terms of how they still like to learn science even they were out of school before and after being exposed to each teaching approach. Meanwhile, in comparing the two groups, the p-value of 0.475 in the conventional group and $0.434 \mathrm{p}$ values in the model-based group revealed that there was no significant difference between the two groups before and after being exposed in their respective treatment. This result indicated that students still love to learn science even when they were not in school. Students enjoyed home-made science experiments or activities like watching television or visiting a science museum in learning science. This attested the findings of Das (2014) that school students by nature are curious, which makes science an ideal subject for it inspires them to explore and study the physical world and discover new things on their own.

Table 8. Attitudes of the participants in the conventional approach and model-based approach before and after the experiment towards future participation in science

\begin{tabular}{llllll}
\hline \multirow{2}{*}{ Attitude } & \multirow{2}{*}{ Method } & \multicolumn{2}{l}{ Mean score } & \multirow{2}{*}{ p-value } & \multirow{2}{*}{ Interpretation } \\
\cline { 2 - 6 } & & Before & After & & \\
\hline \multirow{3}{*}{$\begin{array}{l}\text { Future } \\
\text { Participation } \\
\text { in Science }\end{array}$} & CA & 3.09 & 3.10 & 0.952 & not significant \\
\cline { 2 - 6 } & MBL & 3.19 & 3.18 & 0.909 & not significant \\
\cline { 2 - 6 } & p-value & 0.601 & 0.653 & & \\
\cline { 2 - 5 } & Interpretation & $\begin{array}{l}\text { not } \\
\text { significant }\end{array}$ & $\begin{array}{l}\text { not } \\
\text { significant }\end{array}$ & & \\
\hline
\end{tabular}

Table 8 shows the attitudes of the participants in terms of future participation in Science before and after the experiment. The conventional group (CA) obtained a mean score of 3.09 before the experiment and 3.10 after the experiment with a p-value of 0.952 while the model-based group (MBL) gained a mean score of 3.19 before the experiment and 3.18 mean score after the experiment with a p-value of 0.909 . The results indicated that there was no significant difference concerning students' future participation in science before and after the treatment in each group. This means that students in both groups had the same attitude toward their future involvement in science. Each group was not sure to have future studies or careers related to science before and after being exposed to their respective treatment. On the other hand, in comparing the two groups, the p-value 0.601 obtained before the experiment and 0.653 p-values after the experiment revealed that there was no significant difference between the two groups that means students had the same attitude in terms of taking science courses or job in the future. According to the findings of the study of Kapici \& Akcay (2016), having a positive attitude toward science is one of the important factors that inspire students to continue to study in science. However, due to the complexity of science subjects to grade levels, students' positive interest and attitudes regarding science declines. This result is supported by findings Potvin \& Hasni (2014) that the number of students who were eager to take science-related courses is decreasing. It was found out that the factors inclined to students' present engagement and future participation in science and mathematics are their engagement in science-related 
activities outside of school and the attitudes of their parents towards science as revealed in the study of Reiss \& Ruthven (2011).

Table 9. Attitudes of the participants in the conventional approach and model-based approach before and after the experiment towards importance of science

\begin{tabular}{llllll}
\hline \multirow{2}{*}{ Attitude } & \multirow{2}{*}{ Method } & \multicolumn{2}{l}{ Mean Score } & \multirow{2}{*}{ p-value } & \multirow{2}{*}{ Interpretation } \\
\cline { 3 - 6 } $\begin{array}{l}\text { Importance of } \\
\text { Science }\end{array}$ & $\mathrm{CA}$ & 4.08 & 3.99 & 0.393 & not significant \\
\cline { 2 - 6 } & $\mathrm{MBL}$ & 3.99 & 4.17 & 0.065 & not significant \\
\cline { 2 - 5 } & $\mathrm{p}$-value & 0.536 & 0.284 & & \\
\hline \multirow{2}{*}{ Interpretation } & $\begin{array}{l}\text { not } \\
\text { significant }\end{array}$ & $\begin{array}{l}\text { not } \\
\text { significant }\end{array}$ & & \\
\hline
\end{tabular}

Table 9 shows the attitudes of the participants in terms of the importance of Science before and after the experiment. The mean scores of the conventional group (CA) before and after the experiment were 4.08 and 3.99, respectively with a p-value of 0.393 . Whereas the model-based group (MBL) obtained a mean score of 3.99 before the experiment and 4.17 mean score after the experiment with a p-value of 0.065 . The results indicated that the attitude of students towards science before and after the treatment for each group had no significant difference in connection to importance in science. Students in each group acknowledge and see the importance of science in their lives and of the society before and after being exposed to their respective treatment. Whereas in comparing the two groups, the p-values of 0.526 for the conventional group and $0.284 \mathrm{p}$-values in the model-based group indicated that there was no significant difference between the two which means that both groups had the same attitude towards the importance of science in their lives. In the findings of the study of McFarlane (2013), to appreciate science, as science educators, it should be inculcated in the minds of the students the applied benefits of science in their lives and societal progress, and survival. The transformation of science learning into usable forms that can be applied in daily life situations of students can boost towards greater aspirations in science.

Table 10. Comparison of the participants' performance in earth science using the conventional and model-based learning approach

\begin{tabular}{lllll}
\hline Method & Pretest & Posttest & p-value & Interpretation \\
\hline Conventional approach & 10.3871 & 16.7742 & 0.000 & highly significant \\
\hline Model-based approach & 11.9000 & 18.5333 & 0.000 & highly significant \\
\hline p-value & 0.0660 & 0.1300 & & \\
\hline Interpretation & $\begin{array}{l}\text { not } \\
\text { significant }\end{array}$ & $\begin{array}{l}\text { not } \\
\text { significant }\end{array}$ & & \\
\hline
\end{tabular}

Table 10 depicts the comparison of the computed mean scores on the performance of the participants in earth science in their pretest and posttest. The conventional group had a mean score of 10.3871 in pretest and 16.7742 for the posttest while the modelbased group had a mean score of 11.9000 in the pretest and 18.5333 for the posttest. In comparing pretest and posttest at a $1 \%$ level of significance, the computed p-values were 0.000 for both groups, which implied a highly significant result. Therefore, the 
study reveals that there was a highly significant difference between the pretest and posttest scores of the students, meaning they acquired the needed knowledge and improved their performance as shown in the result of their increased posttest scores after the experiment in each group. On the other hand, in comparing the pretest and posttest of the two groups, the conventional and model-based group had a p-value of 0.066 and 0.130 , respectively which conveyed that there was no significant difference between the two groups which means both groups were comparable in terms of the level of intelligence before and after the treatment; hence, the null hypothesis was rejected. Thus, the findings revealed that the model-based learning approach could be used as an effective alternative to the conventional approach in teaching science as it improved the performance of the students based on the increased posttest scores after the treatment. This supported the previous findings that the use of model-based learning improves students' understanding of science content (Khan, 2007) and promotes scientific literacy (Gobbert et al., 2011). On the other hand, the findings of the study conducted by Thakur (2011) revealed that the traditional or conventional method promotes students' mastery of the subject content and is best applied to subjects that need a detailed explanation of concepts. The teacher guidance in the learning process adheres to the students' level thus promoting great academic impact.

Table 11. SWOT analysis of teacher-respondents' on the model-based learning approach

\begin{tabular}{llll}
\hline \multicolumn{1}{c}{ STRENGTH } & WEAKNESSES & OPPORTUNITIES & \multicolumn{1}{c}{ THREATS } \\
\hline Learning by doing & Needs more time for the task & Less talk for the teachers & Students' misbehavior \\
\hline $\begin{array}{l}\text { Students are the } \\
\text { model maker }\end{array}$ & $\begin{array}{l}\text { Unsuitable when students do } \\
\text { not understand the lesson }\end{array}$ & $\begin{array}{l}\text { It builds student rapport } \\
\text { among themselves }\end{array}$ & $\begin{array}{l}\text { Over-dependent to } \\
\text { the leader }\end{array}$ \\
\hline $\begin{array}{l}\text { There is hands-on } \\
\text { manipulation of } \\
\text { concrete materials }\end{array}$ & $\begin{array}{l}\text { Some students may just } \\
\text { depend on their leader } \\
\text { during group work }\end{array}$ & $\begin{array}{l}\text { It fosters student's critical- } \\
\text { thinking, inventiveness, } \\
\text { and pride for their model }\end{array}$ & $\begin{array}{l}\text { Misconception will } \\
\text { affect the expected } \\
\text { output }\end{array}$ \\
\hline $\begin{array}{l}\text { The product of learning } \\
\text { is the model itself }\end{array}$ & $\begin{array}{l}\text { Students will mislead } \\
\text { if not properly supervised }\end{array}$ & $\begin{array}{l}\text { Students learn thru } \\
\text { collaboration }\end{array}$ & $\begin{array}{l}\text { Availability of } \\
\text { materials }\end{array}$ \\
\hline $\begin{array}{l}\text { Captures students' } \\
\text { attention and interest }\end{array}$ & $\begin{array}{l}\text { Impractical for daily use } \\
\text { due to time requirement }\end{array}$ & $\begin{array}{l}\text { Teachers may learn } \\
\text { from students. }\end{array}$ & $\begin{array}{l}\text { Poor knowledge } \\
\text { of the instruction }\end{array}$ \\
\hline $\begin{array}{l}\text { Motivates students to } \\
\text { work on their own and } \\
\text { learn with their group }\end{array}$ & $\begin{array}{l}\text { Require more time for } \\
\text { model evaluation } \\
\text { and revision }\end{array}$ & $\begin{array}{l}\text { Students learn to solve } \\
\text { problems thru model }\end{array}$ & $\begin{array}{l}\text { Teachers' high } \\
\text { standard on the } \\
\text { building }\end{array}$ \\
$\begin{array}{l}\text { Students' higher-order } \\
\text { thinking skills are } \\
\text { enhanced }\end{array}$ & & $\begin{array}{l}\text { The output model can be } \\
\text { used as instructional aid }\end{array}$ & $\begin{array}{l}\text { Unclear instruction may } \\
\text { increase dead time }\end{array}$ \\
\hline
\end{tabular}

Table 11 shows the perceptions of teacher-respondents towards the model-based learning Approach in terms of its strengths, weaknesses, opportunities, and threats. Based on the analysis, it showed that teachers similarly perceived model-based learning Approach as a learner-centered and teacher-facilitated approach which captures attention, motivates students to develop higher-order thinking skills and develop $21^{\text {st }}$ century skills while working individually and learning collaboratively thru the model building. It provides opportunities for students to practice science by creating a model built from their learning and unlock difficulties through discovery and problem-solving. The output model made by the students can be used as instructional material. This is parallel to the findings of Rodhe (2012) that especially in geosciences the use of model helps students process their learning. Besides, model-based learning enables students to experience the future works of the next generations of scientists, engineers, and 
problem-solvers thru model building (Bryce et al.,2016) thus making it aligned with the goal and principles of $\mathrm{K}$ to 12 Basic Education Program of producing holistically skillcompetent learners (Philippines Department of Education, 2019). These findings are also supported by several studies as cited in the literature review of this study.

On the other hand, regarding the weaknesses of the model-based learning Approach, teachers find it time-consuming especially when students do not understand the science concepts making it hard for them to accomplish the given task. It takes more time also for the evaluation and revision of the output model when students have to improve their output model in line with the given rubric and teacher's suggestions. During the modeling phase, if not supervised properly, students maybe misguided and the output model is affected. For this reason, the teacher's technical supports and closed supervision are important in employing the model-based learning approach. As supported by the findings of Danusso, Testa, \& Vicentini (2010) that teachers must be knowledgeable to address the problems that may arise during the modeling activity.

In connection with threats that may hinder the success of the model-based learning Approach are the students' poor attitudes, misconceptions, and unclear instructions. However, along with all the weaknesses and threats of this approach, the effectiveness and success of model-based learning are on the hands of the teacher itself (Akerson et al., 2009). This suggests that the teacher's expertise, careful planning, and supervision are essential to lessen the dead time and assure the success of using this teaching strategy.

\section{- CONCLUSION}

Based on the findings of the study, the following conclusions were drawn: The Model-Based Learning Approach and Conventional Approach were both effective in enhancing students' academic performance in earth science as revealed in the posttest results. Students who were taught using the model-based learning approach had gained a positive attitude toward science self-concept. This implies that the students developed a positive mindset on how they believe in their ability to do well in the science subject. Last, the SWOT analysis revealed that the model-based learning approach is a learnercentered and teacher-facilitated approach that adheres to the goal and principles of $\mathrm{K}$ to 12 Basic Education Program of enhancing learners interest and motivation, maximizing learners' $21^{\text {st }}$-century skills and scientific skills leading into holistically skill-competent learners through the model building; however, the strategy has limitations when utilizing inside the classroom. These limitations include students' misconceptions, availability of materials, unclear instructions, and time-consuming. It is suggested that the teacher's expertise, careful planning, and supervision are necessary to promote the success in employing the Model-Based Learning Approach. Based on the findings, the Model-Based Learning Approach can be used as an alternative approach to the conventional approach that can help improve students' academic performance and develop a positive mindset in learning science.

\section{- REFERENCES}

Abrahams, I. (2007). An unrealistic image of science. School Science Review, 88(324), $119-122$.

Akcay, H., Yager, R. E., Iskander, S. M. \& Turgut, H. (2010). Change in students' belief about attitudes toward science in grades 6-9. Asia-Pacific Forum on Science Learning and Teaching, 11(1), 1-18. 
Akerson, V.L., Townsend, J.S., Donnelly, L.A., Hanson, D.L., P. Tira, \& White, O., (2009). Scientific modeling for inquiring teachers network (SMITN): The influence on elementary teachers' views of nature of science, inquiry, and modeling. Journal of Science Teacher Education, 20, 21-40.

Ali, M. S., \& Awan, A. S. (2013). Attitude towards science and its relationship with students' achievement in science. Interdisciplinary Journal of Contemporary Research in Business, 4(10), 707-719.

Anderson, L. W., \& Krathwohl, D. R. (2001). A Taxonomy for Learning, Teaching, and Assessing: A revision of Bloom's Taxonomy of Educational Objective ( $1^{\text {st }}$ ed.). NY: Longman

Balliu, V.\& Belshi, M. (2017). Modern teaching versus traditional teaching- albanian teachers between challenges and choices. European Journal of Multidisciplinary Studies, 2(4), 20-26.

Barmby, P. Kind, P. \& Jones, K. (2008). Examining changing attitudes in secondary school science. International Journal of Science Education, 30(8). 1075-1093.

Blumschein, P., Ludwigs, A., Hung, W. \& Jonassen, D. (2009). Model-based approaches to Learning: Using systems models and simulations to improve understanding and problem-solving in complex domains: Sense Publishers.

Bryce, C. M., Baliga, V. B., De Nesnera, K. L., Fiack, D., Goetz, K., Tarjan, L. M., ... \& Ash, D. (2016). Exploring models in the biology classroom. The American Biology Teacher, 78(1), 35-42.

Clement, J. (2008). Creative model construction in scientists and students: The role of imagery, analogy, and mental simulation. Library of Congress: Springer Science

Current Challenges in Basic Science Education. (2010). United nations educational, scientific and cultural organization. Retrieved from http://unesdoc.unesco.org/ images/0019/001914/191425e.pdf

Danusso, L., I. Testa, \& Vicentini, M. (2010). Improving prospective teachers' knowledge about scientific models and modeling: Design and evaluation of a teacher education intervention. International Journal of Science Education, 32(7): 871-905.

Das, M. (2014). Importance of Science in School Curriculum. We School Knowledge Builder. The National Journal, 2, 16-18.

Davis, E. (2011). Design approaches to support pre-service teachers in scientific modeling. Journal of Science Teacher Education, 22(1): 1-21.

Dela Cruz, M. (2017, March 11). Science Ed and thinking society. Philippine Daily Inquirer. https://www.pressreader.com/philippines/philippinedailyinquirer/201703 $11 / 281754154122594$.

DeWitt, J., Archer, L., Osborne, J., Dillon, J., Willis, B., \& Wong, B. (2011). High aspirations but low progression: the science aspirations-careers paradox amongst minority ethnic students. International Journal of Science and Mathematics Education, 9, 243-271.

DeWitt, J., Osborne, J., Archer, L., Dillon, J., Willis, B., ～\& Wong, B. (2013). Young children's aspirations in science: The unequivocal, the uncertain and the unthinkable. International Journal of Science Education, 35(6), 1037-1063.

Fretz, E.B., Wu, H., Zhang, B., Davis, E.A., Krajcik, J.S. \& Soloway, E. (2002). An investigation of software scaffolds supporting modeling practices. Research in Science Education, 32, 567-589 
Gilbert, S., (2011). Models-based science teaching: Understanding and using mental models. Library Congress. U.S.A.: National Science Teachers Association.

Gobert, J. D., O’ Dwyer, L., Horwitz, P., Buckley, B. C., Tal Levy, S., \& Wilensky, U. (2011). Examining the relationship between students' understanding of the nature of models and conceptual learning in Biology, Physics, and Chemistry. International Journal of Science Education, 33(5), 653684.

Guay, F., Chanal, J., Ratelle, C. F., Marsh, H. W., Larose, S. and Boivin, M. (2010), Intrinsic, identified, and controlled types of motivation for school subjects in young elementary school children. British Journal of Educational Psychology, 80, 711-735.

Hacieminoglu, E. (2016). Elementary school students' attitude toward science and related variables. International Journal of Environmental \& Science Education, $11(2), 35-52$.

Halloun, I. A. (2007). Mediated modeling in science education. Science \& Education, $16,653-697$.

Hestenes, D. (2010). Modeling Theory for Math and Science Education. In R. Lesh, C. R. Haines, P. L. Galbraith \& A. Hurford (Eds.), Modeling Students' Mathematical Modeling Competencies (pp. 13-41): Springer US.

Jaiswal, S. \&Choudhuri, R. (2017). Academic self concept and academic achievement of secondary school students. American Journal of Educational Research, 5(10), 1108-1113.

Jansen, M., Schroeders, U., \& Lüdtke, O. (2014). Academic self-concept in science: Multidimensionality, relations to achievement measures, and gender differences. Learning and Individual Differences, 30, 11-21.

Johnson-Laird, P. N. (1983). Mental models. Cambridge, MA: Harvard University Press.

Kapici H. O., \& Akcay, H. (2016). Middle school students' attitudes toward science, scientists, science teachers and classes. Asia-Pacific Forum on Science Learning and Teaching, 17(1).

Khan, S. (2007). Model-based inquiries in chemistry. Science Education, 91(6), 877905.

Lacap, M. (2015). The scientific attitudes of students major in science in the new teacher education curriculum. Asia Pacific Journal of Multidisciplinary Research, $3(5), 7-15$.

Lamanauskas, V. (2009). Gamtamokslinio ugdymo stiprinimo svarba ir būtinumas pradinèje mokykloje. Gamtamokslinis ugdymas / Natural Science Education, Nr. 1(24), 4-7.

Liu, C. \& Long, F. (2014). The discussion of traditional teaching and multimedia teaching approach in college english teaching. Atlantis Press, 31-33.

Louca, L., \& Zacharia, Z. (2012). Modeling-based learning in science education: cognitive, metacognitive, social, material and epistemological contributions. Educational Review, 64(4), 471-492.

Marsh, H. W., \& Martin, A. J. (2011). Academic self-concept and academic achievement: Relations and causal ordering. British Journal of Educational Psychology, 81, 59-77.

McFarlane, D. A. (2013). Understanding the Challenges of Science Education in the $21^{\text {st }}$ Century: New Opportunities for Scientific Literacy. International Letters of Social and Humanistic Sciences, 4, 35-44. 
Meyer, X. (2014). Productive disciplinary engagement as a recursive process: Initial engagement in a scientific investigation as a resource for deeper engagement in the scientific discipline. International Journal of Educational Research, 64, 184195.

Moutinho, S., Moura, R., \& Vasconcelos, C. (2017). Contributions of model-based learning to the restructuring of graduation students' mental models on natural hazards. Eurasia Journal of Mathematics Science and Technology Education, 13(7).

Moutinho, S., \& Vasconcelos, C. (2017). Model-Based Learning applied to natural hazards. Journal of Science Education, 18(2).

National Research Council. (2012). A framework for K-12 science education: Practices, crosscutting concepts, and core ideas. Washington, DC: The National Academies Press.

Needham, R. (2014). The contribution of practical work to the science curriculum. School Science Review, 95(352), 63-69.

NGSS Lead States (2013). Appendix F - science and engineering practices in the NGSS. In Next Generation Science Standards: For States, By States.

Okam, C. C., \& Zakari, I. I. (2017). Impact of laboratory-based teaching strategy on students' attitudes and mastery of chemistry in Katsina Metropolis. International Journal of Innovative Research and Development, 6(1), 112-121.

Passmore, C., Stewart, J., \& Cartier, J. (2009). Model-based inquiry and school science: Creating connections. School Science and Mathematics, 109(7): 394-402.

Philippine Department of Education (2019). PISA 2018 national report of the Philippines. Retrieved from https://www.deped.gov.ph

Potvin, P. \& Hasni, A. (2014). Interest, motivation and attitude towards science and technology at K-12 levels: A systematic review of 12 years of educational research. Studies in Science Education, 50(1), 85-129.

Reiss, M. \& Ruthven, K. (2011). Enhancing the participation, engagement and achievement of young people in science and mathematics education: Introduction. International Journal of Science and Mathematics Education, 9, 239-241.

Rodhe, A. (2012). Physical models for classroom teaching in hydrology. Hydrology and Earth System Sciences.16, 3075-3082.

Schwarz, C. (2009). Developing preservice elementary teachers' knowledge and practices through modeling-centered scientific inquiry. Science Education, 93(4), 720-744.

University of the Philippines National Institute for Science and Mathematics Education Development (UP-NISMED) \& Department of Science and Technology-Science Education Institute (DOS-SEI). (2011). Framework for Philippine science teacher education. Retrieved from http://www.sei.dost.gov.ph.

Soomro, A. Q., Qaisrani, M. N., \& Uqaili, M. A. (2011). Measuring students' attitudes towards learning physics: Experimental research. Australian Journal of Basic and Applied Sciences, 5(11), 2282-2288.

Svoboda, J., \& Passmore, C. (2013). The strategies of modeling in biology education. Science \& Education, 22(1), 119-142.

Thakur, A. (2011). Teaching with modern and traditional methods. Article Atherton JS (2013) Learning and Teaching. Retrieved from http://www.indiastudychannel. com/resources/146615-Teaching-with-modern-and traditional-methods.aspx 
Zwickl, B. M., Hu, D., Finkelstein, N., \& Lewandowski, H. J. (2015). Model-based reasoning in the physics laboratory: Framework and initial results. Physical Review Special Topics-Physics Education Research, 11(2), 020113. 